\title{
Correction to: Multiobjective crashworthiness optimization of graphene type multi-cell tubes under various loading conditions
}

\author{
Accepted: 6 May 2021 / Published online: 31 May 2021 \\ (c) The Brazilian Society of Mechanical Sciences and Engineering 2021

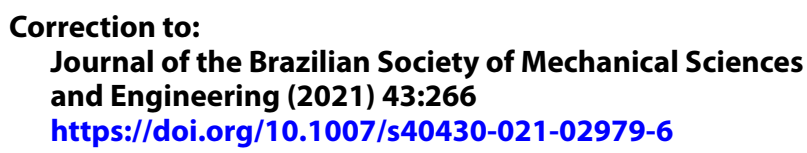

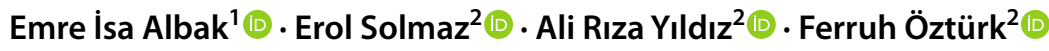

In the original publication of the article, the Conflict of interest section was misspelled as Authors declare that there is conflict of interest to disclose.

It should read as

Conflict of interest Authors declare that there is no conflict of interest to disclose.

The original article has been corrected.

Publisher's Note Springer Nature remains neutral with regard to jurisdictional claims in published maps and institutional affiliations.

The original article can be found online at https://doi.org/10.1007/ s40430-021-02979-6.

Emre İsa Albak

emrealbak@uludag.edu.tr

1 Hybrid and Electric Vehicle Technology, Vocational School of Gemlik Asım Kocabıyık, Bursa Uludağ University, Bursa 16600, Turkey

2 Automotive Engineering Department, Faculty of Engineering, Bursa Uludağ University, Bursa 16059, Turkey 